\title{
南京前中央地翼調查所近訊
}

中央地質調枩所肧杂於一九一二年，正式成 立於一九一六年, 包有三十五年的歷史。一九四九 年四月二十三日南京解放之前, 該所䋓大多数人

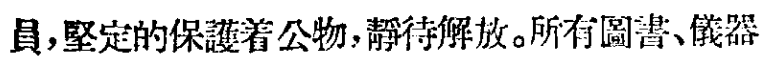
完全操缺的變篇人民財產，這是值得度幸的。因該 所領澺問題末能即時解决, 在一兀四儿年的大伴 年:中,陷入保管状態, 除在南宗附近作一些短期調 槛與整理過去的研究调查資料外, 工作未能大量

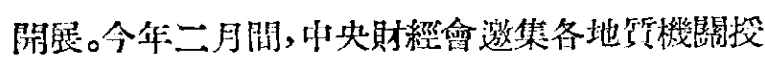

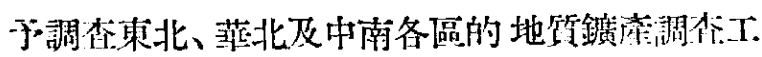

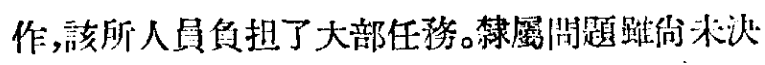
定, 野外調查工作, 先行展閵, 同時室內括究工作 亦漸復常軌。最近情况简略報導如下:

(一)野外調査已經计動地筫及测量人 員三十七，佔該所工作人員百分之九十；大部在 東北各地調查鐵镮及有色金屬。他如大同煤田、山

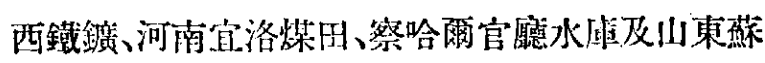

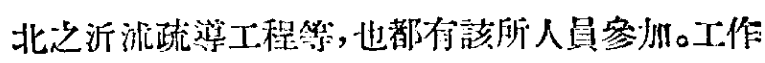
性質包括一般地筑、喍、鐵、有色金屬及工程地質 等项。

（二）地買鏡産圖 該所緛印 百萬分之一

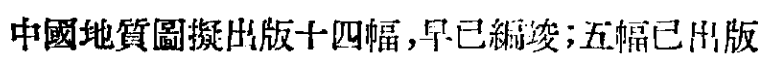

發行, 餘九幅着色在印校中,可能於九月前次第出 版。又三百萬分之一全國地質圖亦在校印中，年内

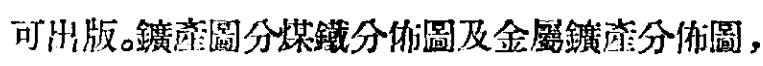
均已最後校對, 即可出版。

\section{（三）土㙫工作 該所士壤調尛與研觉工}

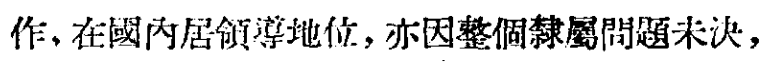

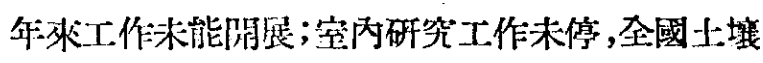
圖也完成了。最近北京舉行的土壤肥料會議給他

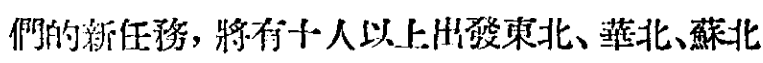
和黄泛㙅工作，配合農栄生產。

\section{（四）地球物理方面 該所地球物理方面} 的工作, 最重要的是地震記錚同研究, 其次是物理 探鐄。近來自製同裝配的多架的地震儀,除自己使 用外，亚鑍揆西北大學一架，準備供給蘭州同北京 地犋调梠所各一套。最重要的是把原有的加利清

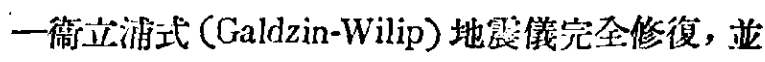
已墔始記錄全世界的地震了。那一真地震儀在抗 戰開始時, 在北京失散了, 腾利後赫獲, 已破壞不 壦，現又隨解放而重新開始工作。同時也正在檢企 同修理探鉞儀器, 準借野外調查隊的需要 而參加 工作。

(衡)

\section{新疆軍區部隊完成巨大水利工程}

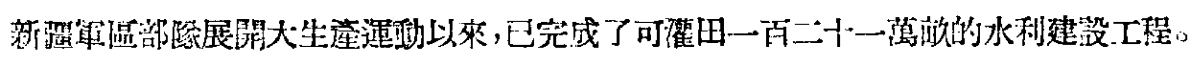

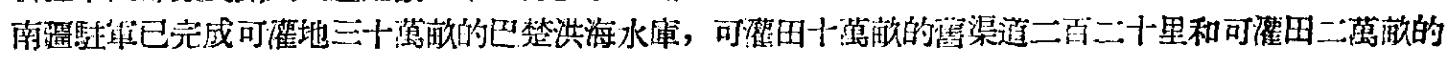

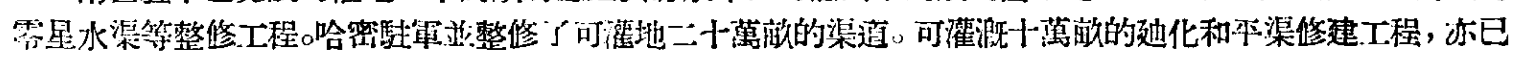

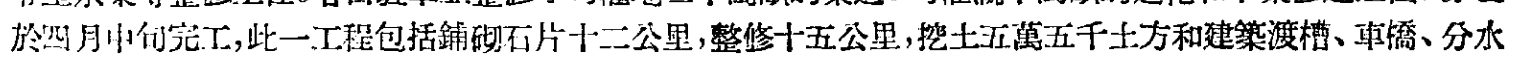
䦌、跌水等.工暡。

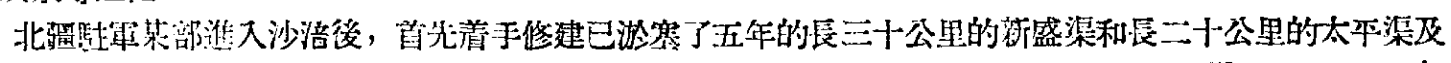

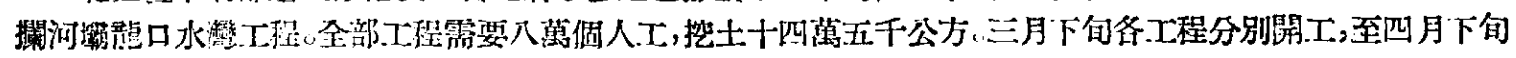

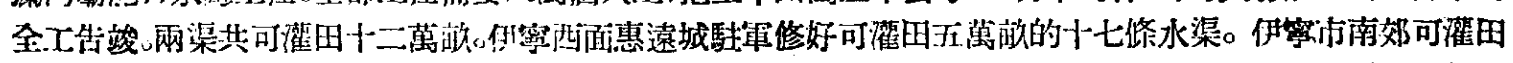

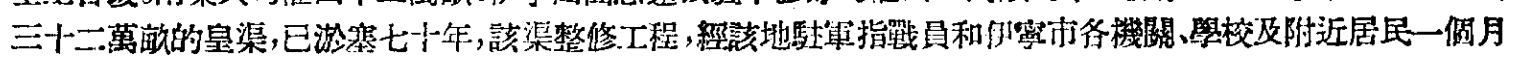

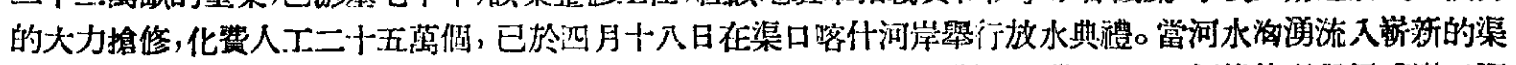

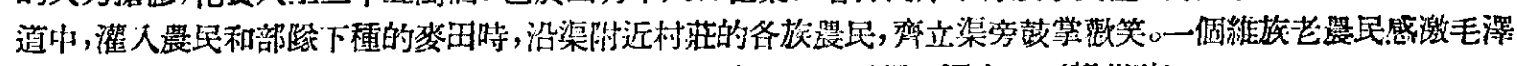

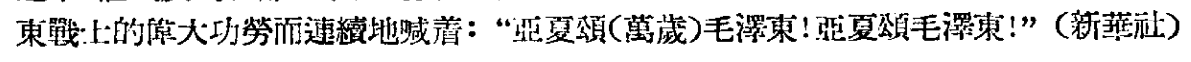

